Invited review

\title{
Store-operated calcium channels and pro-inflammatory signals
}

Wei-chiao $\mathrm{CHANG}^{1}$

Department of Physiology, Anatomy and Genetics, University of Oxford, Oxford, UK

\section{Key words}

calcium channels; store-operated $\mathrm{Ca}^{2+}$ entry; capacitative $\mathrm{Ca}^{2+}$ entry; calcium signaling; mast cells

${ }^{1}$ Correspondence to Dr Wei-chiao CHANG. Phn 44-18-6528-2177.

Fax 44-18-6527-2488.

E-mail wei-chiao.chang@physiol.ox.ac.uk

Received 2006-05-21

Accepted 2006-05-30

doi: $10.1111 / \mathrm{j} .1745-7254.2006 .00395 . \mathrm{x}$

\begin{abstract}
In non-excitable cells such as T lymphocytes, hepatocytes, mast cells, endothelia and epithelia, the major pathway for calcium $\left(\mathrm{Ca}^{2+}\right)$ entry is through store-operated $\mathrm{Ca}^{2+}$ channels in the plasma membrane. These channels are activated by the emptying of intracellular $\mathrm{Ca}^{2+}$ stores, however, neither the gating mechanism nor the downstream targets of these channels has been clear established. Here, I review some of the proposed gating mechanisms of store-operated $\mathrm{Ca}^{2+}$ channels and the functional implications in regulating pro-inflammatory signals.
\end{abstract}

\section{Introduction}

Cells use $\mathrm{Ca}^{2+}$ as a key messenger to regulate a broad spectrum of vital processes. Changes in cytoplasmic $\mathrm{Ca}^{2+}$ can trigger responses as diverse as exocytosis, muscle contraction, enzyme metabolism, gene transcription and cell proliferation ${ }^{[1]}$. To increase cytoplasmic $\mathrm{Ca}^{2+}$ concentration, $\mathrm{Ca}^{2+}$ is either released from intracellular stores or enters the cell by crossing the plasma membrane. In excitable cells, like nerve and muscle, calcium $\left(\mathrm{Ca}^{2+}\right)$ entry is achieved largely through opening the voltage-gated and ligand-gated $\mathrm{Ca}^{2+}$ channels $s^{[2,3]}$. The role of these ion channels is well established and the identity of amino acids in channel properties and gating is well known ${ }^{[2,3]}$. In non-excitable cells, the main mechanism of $\mathrm{Ca}^{2+}$ entryis a process known as "capacitative $\mathrm{Ca}^{2+}$ entry" or "store-operated $\mathrm{Ca}^{2+}$ entry" ${ }^{\text {"[4] }}$. Non-excitable cells do not fire action potentials and voltaged $\mathrm{Ca}^{2+}$ channels are absent ${ }^{[4]}$. Instead, store-operated $\mathrm{Ca}^{2+}$ entry is vital for driving most $\mathrm{Ca}^{2+}$-driven messengers. However, despite considerable research, neither the gating mechanism nor the molecular identity of these channels has been resolved. Here, I review some of the recent findings and theories of the storeoperated $\mathrm{Ca}^{2+}$ entry pathway.

\section{Store-operated $\mathrm{Ca}^{2+}$ entry/capacitative $\mathrm{Ca}^{2+}$ entry}

The model of store-operated $\mathrm{Ca}^{2+}$ entry in non-excitable cells was first proposed in $1986^{[5]}$. The fundamental idea of this model was that the $\mathrm{Ca}^{2+}$ influx pathway could be activated by the amount of calcium in the internal store. As the $\mathrm{Ca}^{2+}$ concentration falls, a signal is sent from the stores to open the $\mathrm{Ca}^{2+}$ channels in the plasma membrane (Figure 1). The first direct evidence in support of the basic tenet of this idea was identified by discovery of a $\mathrm{Ca}^{2+}$ current that was activated by store depletion. The underlying $\mathrm{Ca}^{2+}$ channels were called calcium release-activated calcium channels (CRAC) and this calcium selective current was called $I_{\mathrm{CRAC}}{ }^{[6]}$.

Store-operated $\mathrm{Ca}^{2+}$ channels are the major route of $\mathrm{Ca}^{2+}$ influx in non-excitable cells and the best characterized storeoperated current is $I_{\text {CRAC. }}$ CRAC channels are non-voltage-

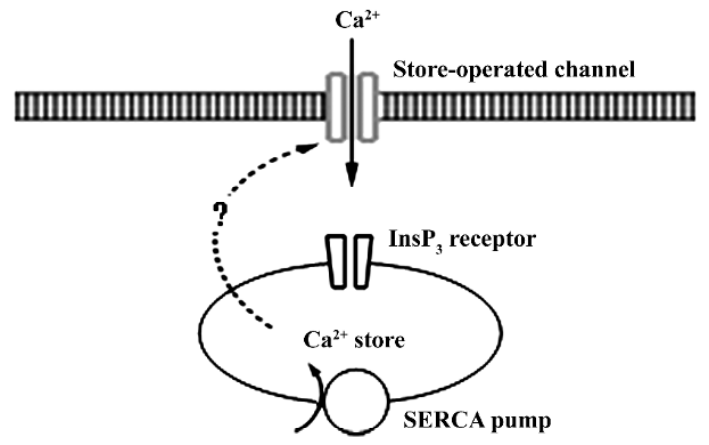

Figure 1. Scheme of capacitative calcium entry/store-operated calcium entry. 
gated channels that are very selective to $\mathrm{Ca}^{2+}\left(\mathrm{P}_{\mathrm{Ca}^{2+}} \mathrm{P}_{\mathrm{Na}}{ }^{+}>\right.$ $1000)$ and have an extremely small conductance for $\mathrm{Ca}^{2+[7]}$. The current is large at negative potentials and approaches the zero current level at positive potentials $(>60 \mathrm{mV})^{[7]}$. CRAC channels require extracellular $\mathrm{Ca}^{2+}$ to maintain their activity. Removal of extracellular $\mathrm{Ca}^{2+}$ results in a slow decline of channel activity ${ }^{[8]}$.

Pharmacology of store-operated $\mathrm{Ca}^{2+}$ channels Storeoperated $\mathrm{Ca}^{2+}$ entry can be evoked by any strategy that lowers the $\mathrm{Ca}^{2+}$ content of the stores ${ }^{[6,7]}$. Physiologically, intracellular stores lose $\mathrm{Ca}^{2+}$ following a rise in the levels of inositol 1, 4, 5-trisphosphate $\left[\operatorname{Ins}(1,4,5) \mathrm{P}_{3}\right]$, which opens ligandgated $\mathrm{Ca}^{2+}$ channels in the endoplasmic reticulum (ER) membrane. Experimentally, stores can be easily emptied following application of endoplasmic reticulum $\mathrm{Ca}^{2+}$ ATPase (SERCA) inhibitors like thapsigargin or exposure of the cytoplasm to high concentrations of $\mathrm{Ca}^{2+}$ chelators such as EGTA or BAPTA that interfere with $\mathrm{Ca}^{2+}$ store refilling and cause passive stores to empty. Other methods of emptying intracellular stores include dialyzing the cytosol with $\operatorname{Ins}(1$, $4,5) \mathrm{P}_{3}$ or permeabilizing the ER membrane to $\mathrm{Ca}^{2+}$ by applying $\mathrm{Ca}^{2+}$ ionophores like ionomycin.

Establishing a link between ion channel activity and activation of physiological functions relies on the use of pharmacological inhibitors. Thus, the issue of how best to block store-operated $\mathrm{Ca}^{2+}$ channels is an important theme in this field. Several pharmacological agents, such as $\mathrm{La}^{3+}$, econazole and SK\&F 96365 are known to inhibit store-operated $\mathrm{Ca}^{2+}$ channels. However, they can also block several other channels over a similar concentration range ${ }^{[9]}$. Thus, they should not be considered specific inhibitors for store-operated $\mathrm{Ca}^{2+}$ channels. 2-Aminoethoxydiphenyl borate (2-APB), an $\mathrm{InsP}_{3}$ receptor inhibitor, has become a popular tool to investigate store-operated $\mathrm{Ca}^{2+}$ channels ${ }^{[10-12]}$. 2-APB is used as an Ins $\mathrm{P}_{3} \mathrm{R}$ antagonist, but growing evidence suggests that it is not simply an $\mathrm{InsP}_{3}$ receptors blocker. For example, $I_{\text {CRAC }}$ in mutant DT40 cells not expressing InsP $_{3}$ receptors can be blocked by $2-\mathrm{APB}$, indicating that targets other than InsP3 receptor are affected ${ }^{[13,14]}$. Therefore, 2-APB seems to directly block the store-operated $\mathrm{Ca}^{2+}$ channels themselves. Another store-operated $\mathrm{Ca}^{2+}$ channel inhibitor is diethylstilbestrol. A synthetic estrogen agonist, diethylstilbestrol has been found to inhibit store-operated $\mathrm{Ca}^{2+}$ entry in human platelets, rat basophilic leukemia cells, and vascular smooth muscle cells but did not affect a whole-cell monovalent cation current mediated by TRPM7 channels ${ }^{[15]}$. Transstilbene, a close structural analog that lacks hydroxyl and ethyl groups, had no effect on store-operated $\mathrm{Ca}^{2+}$ influx ${ }^{[15]}$.
Mitochondrial regulation of store-operated $\mathrm{Ca}^{2+}$ channels Mitochondria play an important role in production of ATP in eukaryotic cells. However, evidence has revealed that mitochondria can rapidly take up a great amount of calcium that has entered through different $\mathrm{Ca}^{2+}$ channels ${ }^{[16-19]}$. Can storeoperated $\mathrm{Ca}^{2+}$ channels be regulated by the mitochondria? An elegant series of experiments establishing how mitochondrial $\mathrm{Ca}^{2+}$ uptake regulates store-operated $\mathrm{Ca}^{2+}$ channels has come from work on rat basophilic leukaemia (RBL) cells and $\mathrm{T}$ lymphocytes ${ }^{[20,21]}$. In RBL cells, mitochondria are also necessary for the activation of $\mathrm{I}_{\mathrm{CRAC}}$ under physiological conditions of weak intracellular $\mathrm{Ca}^{2+}$ buffering. Whole cell dialysis with $\operatorname{Ins}(1,4,5) \mathrm{P}_{3}$ fails to activate any detectable $I_{\text {CRAC }}$ unless mitochondria are in an energized state ${ }^{[20,22]}$. Mitochondrial depolarization using electron transport chain blockers, such as antimycin A or rotenone, prevented $I_{\text {CRAC }}$ from developing, and the size of $I_{\mathrm{CRAC}}$ to thapsigargin could be increased by energized mitochondria ${ }^{[20,22]}$. In T lymphocytes, moreover, energized mitochondria reduced $\mathrm{Ca}^{2+}$-dependent slow inactivation, thereby prolonging the timecourse of $\mathrm{Ca}^{2+}$ influx. Inhibition of mitochondrial $\mathrm{Ca}^{2+}$ uptake by $\mathrm{CCCP}$ or antimycin $\mathrm{A}$ enhance $\mathrm{Ca}^{2+}$-dependent inactivation of $I_{\mathrm{CRAC}}{ }^{[21]}$. Moreover, functional mitochondria are required to sustain CRAC channel activity, and downstream transcription factor NFAT translocation ${ }^{[21]}$.

\section{Mechanism of store-operated $\mathrm{Ca}^{2+}$ channel activation}

The activation mechanism of store-operated $\mathrm{Ca}^{2+}$ channels is one of the most intriguing mysteries. In the past few years, several models have been proposed to explain the link between store emptying and $\mathrm{Ca}^{2+}$ influx. Although there is evidence to support each model, there is also evidence that can not be easily fitted into any. In this review, I focus on different activation models (Figure 2 ) of store-operated $\mathrm{Ca}^{2+}$ channels.

Diffusible messenger model Randriamampita and Tsien were the first to propose the existence of a small diffusible molecule that activated store-operated $\mathrm{Ca}^{2+}$ channels ${ }^{[23]}$. This molecule was named calcium influx factor (CIF), and is released following $\mathrm{Ca}^{2+}$ store depletion and translocates to the plasma membrane to activate store-operated $\mathrm{Ca}^{2+}$ channels. CIF is a phosphorylated molecule that could be degraded by okadaic acid-sensitive protein phosphatases [24]. CIF produced by either mammalian cells or yeast with depleted $\mathrm{Ca}^{2+}$ stores directly activates store-operated $\mathrm{Ca}^{2+}$ channels in vascular smooth muscle cells ${ }^{[25]}$, and is able to accelerate the development of $I_{\text {CRAC }}$ in Jurkat T lymphocytes 

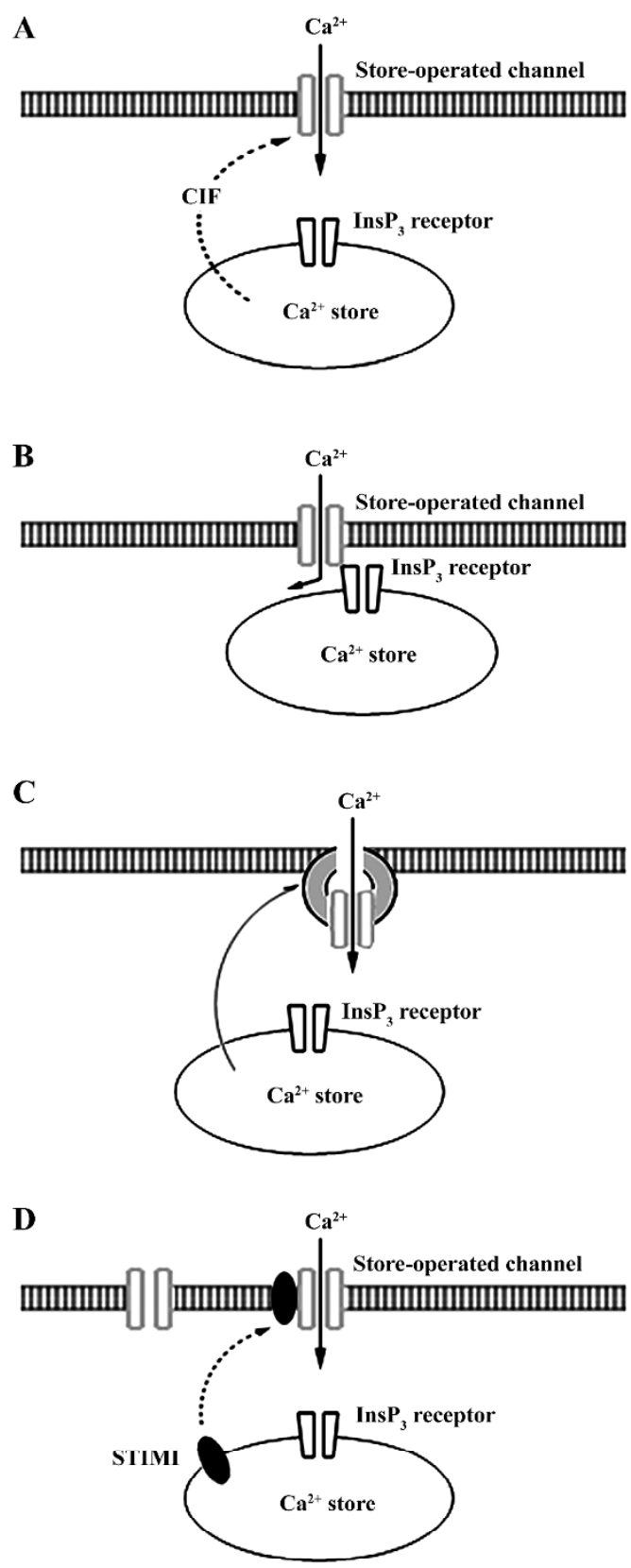

Figure 2. Four models proposed to explain the activation mechanism of store-operated calcium channels. (A) diffusible messenger model; (B) conformational coupling model; (C) vesicular fusion model; (D) calcium sensor model.

and RBL-2H3 cells ${ }^{[26,27]}$. Although recent work on CIF is encouraging, it is still not known how CIF activates storeoperated $\mathrm{Ca}^{2+}$ channels. Further evidence in support of the CIF model has come from work in smooth muscle cells ${ }^{[28]}$. Smani et $a l^{[28]}$ reported that calcium-independent phospholipase $\mathrm{A}_{2}$ was essential for CIF-mediated $\mathrm{Ca}^{2+}$ influx. In this model, CIF disassociates inhibitory calmodulin from calcium- independent phospolipase $\mathrm{A}_{2}\left(\mathrm{iPLA}_{2}\right)$, leading to activation of iPLA $_{2}$ then LysoPLs, which in turn open store-operated $\mathrm{Ca}^{2+}$ channels in the plasma membrane ${ }^{[28]}$. Importantly, both the pharmacological iPLA 2 inhibitor bromoenol lactone and antisense oligonucleotides directed against iPLA $\mathrm{A}_{2}$ suppress the activation of store-operated $\mathrm{Ca}^{2+}$ channels following either with thapsigargin or $\mathrm{CIF}^{[28]}$. These recent studies support a role of iPLA $_{2}$ and LysoPLs in the CIF model.

Conformational coupling model Berridge and Irvine ${ }^{[29,30]}$ first proposed a mechanism of connection between ER and store-operated $\mathrm{Ca}^{2+}$ channels that involves a direct proteinprotein interaction. According to this model, $\operatorname{Ins}(1,4,5) \mathrm{P}_{3}$ receptors in the ER could be physically associated to storeoperated $\mathrm{Ca}^{2+}$ channels in the plasma membrane. Store emptying could change the conformation of $\operatorname{Ins}(1,4,5) \mathrm{P}_{3}$ receptors, which then regulates the opening of store-operated channels through protein-protein interaction. This idea of conformational coupling was indirectly supported by works on $\operatorname{Ins}(1,4,5) \mathrm{P}_{3}$ receptors and the canonical TRP family, which are candidates for store-operated channels ${ }^{[31,32]}$. In HEK293 cells, recombinant TRPC3 channels can be co-immunoprecipitated with $\operatorname{Ins}(1,4,5) \mathrm{P}_{3}$ receptors $^{[33]}$. Kiselyov et al ${ }^{[31,34]}$ also showed that the N-terminal domain of type $1 \operatorname{Ins}(1,4,5)$ $\mathrm{P}_{3}$ receptors is involved in the activation of TRPC3. Similarly, studies done in human platelets have revealed the interaction between TRPC1 and type II Ins(1,4,5)P3 receptors $^{[32]}$. However, there are some studies documenting that Ins(1,4, 5) $\mathrm{P}_{3}$ receptors are not essential for the activation of storeoperated channels. For example, $I_{\mathrm{CRAC}}$ in mutant DT40 cells not expressing all three types of $\mathrm{InsP}_{3}$ receptors can still be activated by thapsigargin, indicating physical coupling might not be essential in the activation of CRAC channels ${ }^{[35]}$. These findings fit with observations by other groups, all of which reported that heparin, an $\mathrm{IP}_{3}$ receptor antagonist, did not interfere with the activation of $I_{\mathrm{CRAC}}$ in RBL cells or DT40 chicken B cells ${ }^{[36-38]}$. Thus, in some cell types, conformational coupling between $\operatorname{Ins}(1,4,5) \mathrm{P}_{3}$ receptor and store-operated channels might not be required for the activation of $I_{\text {CRAC. }}$

Vesicular fusion model The third model to explain the activation mechanism of store-operated $\mathrm{Ca}^{2+}$ channels is vesicular fusion. This hypothesis suggests that store emptying causes store-operated $\mathrm{Ca}^{2+}$ channels to be inserted into the plasma membrane using an exocytotic mechanism. Yao et $a l^{[39]}$ first reported the vesicular fusion model in Xenopus oocytes. They found $I_{\mathrm{CRAC}}$ was disrupted by overexpression of a mutant of SNAP-25, indicating functional SNAP-25 is necessary to activate store-operated $\mathrm{Ca}^{2+}$ current $^{[39]}$. In rat megakaryocytes, the vesicular transport in- 
hibitor primaquine was found to block the development of $I_{\mathrm{CRAC}}$, suggesting the involvement of exocytotic mechanisms ${ }^{[40]}$. In HEK-293 cells, Alderton et $a l^{[41]}$ reported that direct microinjection of botulinum neurotoxin $\mathrm{A}$ and tetanus neurotoxin, which cleaves SNAP-25 and specifically hydrolyzes vesicle-associated membrane protein 2, respectively, impaired store-operated $\mathrm{Ca}^{2+}$ entry. However, there is evidence indicating that SNAP-25 might not be involved in the activation of store-operated $\mathrm{Ca}^{2+}$ entry. The major challenge to the vesicular fusion model came from studies on the expression of SNAP-25 in nonexcitable cells. Scott et $a l^{[42]}$ found that neither HEK-293 nor COS-1 cell lysates had detectable levels of SNAP-25. In contrast, both HEK-293 and COS-1 cells express high levels of botulinum neurotoxin Ainsensitive SNAP-23 protein. In spite of the overexpression of mutant SNAP-23, store-operated $\mathrm{Ca}^{2+}$ entry was unaffected. In RBL cells, Bakowski et $a l^{[43]}$ reported that recombinant protein alpha-SNAP1-285, an inhibitor of exocytosis, inhibited vesicular fusion but had no effect on the activation of $I_{\mathrm{CRAC}}$. Hence, vesicular fusion does not seem to be involved in the activation of $I_{\text {CRAC }}$.

Calcium sensor model In 2005, some exciting results came from Roos et $a l^{[44]}$ in the elusive mechanism of storeoperated $\mathrm{Ca}^{2+}$ channels. They applied an RNAi-mediated silencing screen to 170 genes in Drosophila S2 cells, including a number of transient receptor potential genes, and used thapsigargin-evoked $\mathrm{Ca}^{2+}$ entry as a marker for store-operated channels. One gene coding for a protein called stromal interaction molecule (STIM) significantly reduced thapsigargin-induced store-operated $\mathrm{Ca}^{2+}$ influx. They also comfirmed that STIM1 knockout in Jurkat T cells was abolished in $I_{\text {CRAC. }}{ }^{[44]}$. Similarly, after screening 2,304 proteins, Liou et $a l^{[45]}$ identified two proteins, STIM1 and STIM2, that are essential for maintaining the store-operated $\mathrm{Ca}^{2+}$ entry in HeLa cells.

The $\mathrm{NH}_{2}$-terminal domain of STIM1 contains an $\alpha$ helices structure called EF hand motif, and a protein-protein interaction domain called the sterile $\alpha$ motif $(\mathrm{SAM})^{[45]}$. Because of the EF hand motif, STIM1 is likely to be within the lumen of ER. STIM1 might function as the calcium sensor within stores $^{[45]}$. By transfecting fluorescent fusion protein to detect the localization of STIM1, Liou et $a l^{[45]}$ reported the redistribution of YFP-STIM1 into puncta near plasma membrane was triggered by thapsigargin-induced store depletion. Interestingly, when the calcium-binding aspartic acid residue in the EF hand motif was mutated to alanine, store emptying failed to trigger any store-operated $\mathrm{Ca}^{2+}$ influx ${ }^{[45]}$.

Zhang et $a l^{[46]}$ were the first to report that stores depletion results in the translocation of endogenous STIM1 from
ER to plasma membrane. They showed that mutation of the EF hand motif that mimics store emptying triggered the activation and translocation of store-operated $\mathrm{Ca}^{2+}$ channels ${ }^{[46]}$. Further evidence supporting the STIM1 model showed that overexpression of STIM1 resulted in a substantial increase in $I_{\text {CRAC }}$ and mutants in the EF hand motif and $\mathrm{C}$ terminal of STIM1 altered the basic features of CRAC channels ${ }^{[47]}$. The study indicates that, in addition to being a calcium sensor within ER, STIM1 within the plasma membrane might function as a regulatory component of store-operated $\mathrm{Ca}^{2+}$ channels ${ }^{[47]}$. Thus, a new model proposes that STIM1 is located in the membrane of ER when stores are full. Once stores are empty, $\mathrm{Ca}^{2+}$ dissociates from the EF hand motif of STIM1, and STIM1 translocates to plasma membrane to activate CRAC channels. More data supports the involvement of STIM1 in the regulation of store-operated $\mathrm{Ca}^{2+}$ channels. Thus, the goal for understanding the mechanism of storeoperated $\mathrm{Ca}^{2+}$ channels activation seems to be a real possibility.

\section{Physiological function of store-operated $\mathrm{Ca}^{2+}$ channels}

There is growing evidence for a role of store-operated $\mathrm{Ca}^{2+}$ influx in human disease. Severe combined immunodeficiency ${ }^{[48,49]}$ and acute pancreatitis ${ }^{[50,51]}$ have been linked to a failure of store-operated $\mathrm{Ca}^{2+}$ entry. Actually, the increase of intracellular $\mathrm{Ca}^{2+}$ through CRAC channels can regulate several inflammatory processes. This review will focus on studies over the past several years that have been aimed at understanding the activation of pro-inflammatory signals such as transcription factor nuclear factor $\kappa \mathrm{B}(\mathrm{NF}-\kappa \mathrm{B})^{[52-54]}$, nuclear factor of activated T cells (NF-AT) ${ }^{[52-54]}$, endothelial nitric oxide synthase (eNOS) ${ }^{[55]}$, and leukotrienes ${ }^{[56]}$ by storeoperated $\mathrm{Ca}^{2+}$ channels.

NF-KB and NF-AT These two transcription factors play important roles in immunity, cell proliferation and proinflammatory cytokine gene activation ${ }^{[52-54,57-59]}$. NF- $\kappa \mathrm{B}$ is considered to be a pro-inflammatory initiator that can be activated by different stimuli such as lipopolysaccharide ${ }^{[60,61]}$, ER stress $^{[62]}$. Decoy receptor 3 signalling ${ }^{[63]}$, tumor necrosis factor ${ }^{[58,59]}$ and variations of the $\mathrm{Ca}^{2+}$ oscillations amplitude ${ }^{[52-54]}$. Similarly, NF-AT is a family of transcription factors that regulate gene expression during the immune response. The activation of NF-AT is tightly regulated by the $\mathrm{Ca}^{2+}$ /calmodulin-dependent serine phosphatase calcineurin. In resting cells, phosphorylated NF-AT localizes in the cytoplasm but, after stimulation by calcium rise, calcineurin is activated, resulting in dephosphorylation of NF-AT. NFA-T translocates to the nucleus and stimulates gene transcription ${ }^{[64-66]}$. Delmetsch et a ${ }^{[52]}$ first reported the 
involvement of $\mathrm{Ca}^{2+}$ oscillations through CRAC channels in the regulation of transcription factors NF-AT, Oct/Oap and $\mathrm{NF}-\kappa \mathrm{B}$ in T cells. Different frequencies of $\mathrm{Ca}^{2+}$ oscillations resulted in different molecular mechanisms for transcription factor activation ${ }^{[52-54]}$. For example, high frequency of $\mathrm{Ca}^{2+}$ oscillations activated all three transcription factors, but low frequency $\mathrm{Ca}^{2+}$ oscillations only induced NF- $\kappa \mathrm{B}$ activation. The changes in $\mathrm{Ca}^{2+}$ oscillations have been extended to control target gene activation, as well as to induce downstream immune response and inflammation. In Jurkat T cells, a sustained $\mathrm{Ca}^{2+}$ influx through CRAC channels is critical for transcription of NF-AT and the expression of the interleukin (IL)2 gene $^{[52-54]}$. YM-58483, a pyrazole derivative, potently inhibited thapsigargin-induced $\mathrm{Ca}^{2+}$ entry, NF-AT transcriptional activity and IL-2 production, but not AP-1-driven promoter activity, indicating that $\mathrm{Ca}^{2+}$ entry is able to drive different types of transcription factors ${ }^{[67]}$.

eNOS An increase in vascular permeability is an important sign of acute inflammatory process. Several mediators, such as histamine, bradykinin, prostaglandins and nitric oxide are kown to be involved in vascular permeability changes ${ }^{[68]}$. eNOS is a calcium/calmodulin-dependent enzyme constitutively expressed in endothelial cells. eNOS-derived nitric oxide has an important role in some of the features of inflammation, such as cell rolling, vascular permeability and angiogenesis $^{[68]}$. In human endothelial cells, eNOS can be regulated by lysophosphatidylcholine ${ }^{[69-71]}$ through a dynamic interaction between casein kinase 2 and serine/threonine phosphatase $2 \mathrm{~A}$ in $\mathrm{Sp} 1$ binding activity. In pulmonary artery endothelial cells, the SERCA inhibitor thapsigargin can activate nitric oxide production ${ }^{[72]}$. However, it is not known whether this activation is caused by $\mathrm{Ca}^{2+}$ release from intracellular stores or $\mathrm{Ca}^{2+}$ influx through store-operated $\mathrm{Ca}^{2+}$ channels. The first example of how store-operated $\mathrm{Ca}^{2+}$ influx can activate eNOS came from Lin et $a l^{[73]}$. Their results indicated that membrane-associated wild-type eNOS enzymatic activity is more sensitive to $\mathrm{Ca}^{2+}$ entry through storeoperated $\mathrm{Ca}^{2+}$ channels than the release from intracellular stores. Because the localization of wild-type nitric oxide synthase is very close to store-operated $\mathrm{Ca}^{2+}$ channels, this colocalization could contribute to the rapid activation of nitric oxide synthase by $\mathrm{Ca}^{2+}$ entry ${ }^{[73]}$.

Arachidonic acid and leukotrienes In rat basophilic leukemia cells, $\mathrm{Ca}^{2+}$ entry through CRAC channels drivered exocytosis $^{[74]}$. Among the influential molecules released from mast cells are the leukotrienes that regulate a variety of inflammatory reactions ${ }^{[75]}$. Chang and Parekh ${ }^{[56]}$ first described the involvement of CRAC channels in the regulation of pro- inflammatory signals by arachidonic acid and leukotriene $\mathrm{C}_{4}$ in RBL cells. Transient activation of CRAC channels following a 4 min stimulation by thapsigargin was sufficient to generate a significant increase in pro-inflammatory signals. Calcium influx through CRAC channels, but not calcium release from intracellular stores, stimulated arachidonic acid production $^{[56]}$. Arachidonic acid can be metabolized by 5-lipoxygenase enzyme, leading to the formation of leukotrienes. In the regulation mechanism of $\mathrm{LTC}_{4}$ secretion, calcium entry through CRAC channels activates extracellular signal regulated kinase (ERKs) within minutes and this is necessary for stimulation of $\mathrm{cPLA}_{2}{ }^{[76]}$. $\mathrm{Ca}^{2+}$ entry activates ERK indirectly, via stimulation of calcium-dependent protein kinase $\mathrm{C}$ isozymes $\alpha$ and $\beta \mathrm{I}^{[76]}$. Following opening of CRAC channels, protein kinase $\mathrm{C}$ isozymes $\alpha$ and $\beta \mathrm{I}$ translocate from the cytosol to plasma membrane. Acute inhibition of these isozymes or down regulation following chronic exposure to phorbol ester prevents $\mathrm{Ca}^{2+}$ entry from activating ERK, $\mathrm{cPLA}_{2}$ and $\mathrm{LTC}_{4}{ }^{[76]}$. Although phorbol ester (PKC activator) stimulation resulted in strong ERK phosphorylation, this was not associated with any arachidonic acid release nor $\mathrm{LTC}_{4}$ secretion. Therefore, activation of $\mathrm{PKC}$ and subsequent phosphorylation of ERK1/2 in the absence of a $\mathrm{Ca}^{2+}$ signal is not sufficient to activate $\mathrm{cPLA}_{2}$. Instead, both $\mathrm{Ca}^{2+}$ and $\mathrm{PKC} /$ ERK are needed. Neither stimulates alone, in the absence of the other, can trigger arachidonic acid and $\mathrm{LTC}_{4}$ secretion $^{[76]}$. Importantly, mitochondrial depolarization, by impairing $\mathrm{Ca}^{2+}$ entry through CRAC channels, suppressed the phosphorylation of ERK, release of arachidonic acid and downstream $\mathrm{LTC}_{4}$ secretion. The results establish the importance of mitochondrial regulation of CRAC channel activity in determining subsequent downstream pro-inflammatory molecules ${ }^{[56]}$.

\section{Conclusion}

Store-operated $\mathrm{Ca}^{2+}$ channels have an essential role in the short-term and long-term regulation of the inflammatory process. In light of the fact that NF- $\kappa \mathrm{B}, \mathrm{NF}-\mathrm{AT}$, eNOS activation and $\mathrm{LTC}_{4}$ secretion are very potent pro-inflammatory mediators and have been linked to chronic inflammatory disease such as arthritis, atherosclerosis and asthma, CRAC channels could be a rational therapeutic target for treating such disorders.

\section{Acknowledgements}

I am grateful to Prof Anant PAREKH for reading this paper, and Wan-chen HUANG for help with the figures. Dr Wei-chiao CHANG is in receipt of an ORS studentship. 


\section{References}

1 Berridge MJ, Bootman MD, Roderick HL. Calcium signalling: dynamics, homeostasis and remodelling. Nat Rev Mol Cell Bio 2003; 4: 517-29

2 Burnashev N. Calcium permeability of ligand-gated channels. Cell Calcium1 998; 24: 325-32.

3 Catterall WA. Structure and regulation of voltage-gated $\mathrm{Ca}^{2+}$ channels. Annu Rev Cell Dev Biol 2000; 16: 521-55.

4 Parekh AB, Putney JW Jr. Store-operated calcium channels. Physiol Rev 2005; 85: 757-810.

5 Putney JW Jr. Capacitative calcium entry in the nervous system. Cell Calcium 2003; 34: 339-44.

6 Hoth M, Penner R. Depletion of intracellular calcium stores activates a calcium current in mast cells. Nature 1992; 355: 353-6.

7 Parekh AB, Penner R. Store-operated calcium influx. Physiol Rev 1997; 77: 901-30.

8 Zweifach A, Lewis RS. Calcium-dependent potentiation of storeoperated calcium channels in T lymphocytes. J Gen Physiol 1996; 107: 597-610.

9 Franzius D, Hoth M, Penner R. Non-specific effects of calcium entry antagonists in mast cells. Pflügers Arch 1994; 428: 433-8.

10 Bakowski D, Glitsch MD, Parekh AB. An examination of the secretion-like coupling model for the activation of the $\mathrm{Ca}^{2+}$ release-activated $\mathrm{Ca}^{2+}$ current $I_{\text {CRAC }}$ in RBL-1 cells. J Physiol 2001; 532: 55-71.

11 Prakriya M, Lewis RS. Potentiation and inhibition of $\mathrm{Ca}^{2+}$ release-activated $\mathrm{Ca}^{2+}$ channels by 2 -aminoethyldiphenyl borate (2-APB) occurs independently of $\mathrm{IP}_{3}$ receptors. J Physiol 2001; 536: 3-19.

12 Voets T, Prenen J, Fleig A, Vennekens R, Watanabe H, Hoenderop JGJ, et al. CaT 1 and the calcium release-activated calcium channel manifest distinct pore properties. J Biol Chem 2001; 276: 47767-70.

13 Broad LM, Braun FJ, Lievremont JP, Bird GSJ, Kurosaki T, Putney JW Jr. Role of the phospholipase C-inositol 1,4,5-trisphosphate pathway in calcium release-activated calcium current and capacitative calcium entry. J Biol Chem 2001; 276: 15945-52.

14 Ma HT, Venkatachalam K, Li HS, Montell C, Kurosaki T, Patterson RL, et al. Assessment of the role of the inositol 1,4, 5 -trisphosphate receptor in the activation of transient receptor potential channels and store-operated $\mathrm{Ca}^{2+}$ entry channels. J Biol Chem 2001; 276: 18888-96.

15 Zakharov SI, Smani T, Dobrydneva Y, Monje F, Fichandler C, Blackmore PF, et al. Diethylstilbestrol is a potent inhibitor of store-operated channels and capacitative $\mathrm{Ca}^{2+}$ influx. Mol Pharmacol 2004; 66: 702-7.

16 Rizzuto R, Brini M, Murgia M, Pozzan T. Microdomains with high $\mathrm{Ca}^{2+}$ close to $\mathrm{IP}_{3}$-sensitive channels that are sensed by neighboring mitochondria. Science 1993; 262: 744-7.

17 Jouaville LS, Ichas F, Holmuhamedov EL, Camacho P, Lechleiter JD. Synchronization of calcium waves by mitochondrial substrates in Xenopus laevis oocytes. Nature 1995; 377: 438-41.

18 Hajnoczky G, Hager R, Thomas AP. Mitochondria suppress local feedback activation of inositol 1, 4, 5-trisphosphate receptors by $\mathrm{Ca}^{2+}$. J Biol Chem 1999; 274: 14157-62.

19 Arnaudeau S, Kelley WL, Walsh JV, Demaurex N. Mitochondria recycle $\mathrm{Ca}^{2+}$ to the endoplasmic reticulum and prevent the deple- tion of neighbouring endoplasmic reticulum regions. J Biol Chem 2001; 276: 29430-9

20 Gilabert JA, Parekh AB. Respiring mitochondria determine the pattern of activation and inactivation of the store-operated $\mathrm{Ca}^{2+}$ current $I_{\text {CRAC. }}$ EMBO J 2000; 19: 6401-7.

21 Hoth M, Button D, Lewis RS. Mitochondrial control of calcium channel gating: a mechanism for sustained signaling and transcriptional activation in T lymphocytes. Proc Natl Acad Sci USA 2000; 97: 10607-12.

22 Gilabert JA, Bakowski D, Parekh AB. Energized mitochondria increase the dynamic range over which inositol 1,4,5-trisphosphate activates store-operated calcium influx. EMBO J 2001; 20: 2672-9.

23 Randriamampita C, Tsien RY. Emptying of intracellular $\mathrm{Ca}^{2+}$ stores releases a novel small messenger that stimulates $\mathrm{Ca}^{2+}$ influx. Nature 1993; 364: 809-84.

24 Randriamampita C, Tsien RY. Degradation of a calcium influx factor (CIF) can be blocked by phosphatase inhibitors or chelation of $\mathrm{Ca}^{2+}$. J Biol Chem 1995; 270: 29-32.

25 Trepakova ES, Gericke M, Hirakawa Y, Weisbrod RM, Cohen RA, Bolotina VM. Properties of a native cation channel activated by $\mathrm{Ca}^{2+}$ store depletion in vascular smooth muscle cells. J Biol Chem 2001; 276: 7782-90.

26 Csutora P, Su Z, Kim HY, Bugrim A, Cunningham KW, Nuccitelli $\mathrm{R}$, et al. Calcium influx factor is synthesized by yeast and mammalian cells depleted of organellar calcium stores. Proc Natl Acad Sci USA 1999; 96: 121-6.

27 Su Z, Csutora P, Hunton RL, Shoemaker RB, Marchase RB, Blalock JE. A store-operated nonselective cation channel in lymphocytes is activated directly by $\mathrm{Ca}^{2+}$ influx factor and diacylglycerol. Am J Physiol Cell Physiol 2001; 280: C1284C1292.

28 Smani T, Zakharov SI, Csutora P, Leno E, Trepakova ES, Bolotina VM. A novel mechanism for the store-operated calcium influx pathway. Nature Cell Biol 2004; 6: 113-20.

29 Berridge MJ. Capacitative calcium entry. Biochem J 1995; 312 : $1-11$.

30 Irvine RF. Quantal $\mathrm{Ca}^{2+}$ release and the control of $\mathrm{Ca}^{2+}$ entry by inositol phosphates - a possible mechanism. FEBS Lett 1990; 263: 3-5.

31 Kiselyov K, Mignery GA, Zhu MX, Muallem S. The N-terminal domain of the $\mathrm{IP}_{3}$ receptor gates store-operated hTrp3 channels. Mol Cell 1999; 4: 423-9.

32 Rosado JA, Brownlow SL, Sage SO. Endogenously expressed TRP1 is involved in store-mediated $\mathrm{Ca}^{2+}$ entry by conformational coupling in human platelets. J Biol Chem 2002; 277: 42157-63.

33 Bird GS, Putney JW Jr. Effect of inositol 1,3,4,5tetrakisphosphate on inositol trisphosphate-activated $\mathrm{Ca}^{2+}$ signaling in mouse lacrimal acinar cells. J Biol Chem 1996; 271 : 6766-70.

34 Kiselyov K, Xu X, Mozhayeva G, Kuo T, Pessah I, Mignery G, et al. Functional interaction between $\mathrm{InsP}_{3}$ receptors and storeoperated Htrp3 channels. Nature 1998; 396: 478-82.

35 Sugawara H, Kurosaki M, Takata M, Kurosaki T. Genetic evidence for involvement of type 1, type 2 and type 3 inositol 1,4, 5 -trisphosphate receptors in signal transduction through the Bcell antigen receptor. EMBO J 1997; 16: 3078-88. 
36 Bakowski D, Glitsch MD, Parekh AB. An examination of the secretion-like coupling model for the activation of the $\mathrm{Ca}^{2+}$ release-activated $\mathrm{Ca}^{2+}$ current $I_{\mathrm{CRAC}}$ in RBL-1 cells. J Physiol 2001; 532: 55-71.

37 Fierro L, Parekh AB. On the characterisation of the mechanism underlying passive activation of the $\mathrm{Ca}^{2+}$ release-activated $\mathrm{Ca}^{2+}$ current $I_{\text {CRAC }}$ in rat basophilic leukaemia cells. J Physiol 1999; 520: 407-16.

38 Broad LM, Braun FJ, Lievremont JP, Bird GSJ, Kurosaki T, Putney JW Jr. Role of the phospholipase C-inositol 1,4,5-trisphosphate pathway in calcium release-activated calcium current and capacitative calcium entry. J Biol Chem 2001; 276: 15945-52.

39 Yao Y, Ferrer-Montiel AV, Montal M, Tsien RY. Activation of store-operated $\mathrm{Ca}^{2+}$ current in Xenopus oocytes requires SNAP25 but not a diffusible messenger. Cell 1999; 98: 475-85.

40 Somasundaram B, Norman JC, Mahaut-Smith MP. Primaquine, an inhibitor of vesicular transport, blocks the calcium releaseactivated calcium current in rat megakaryocytes. Biochem $\mathrm{J}$ 1995; 309: 725-9.

41 Alderton JM, Ahmed SA, Smith LA, Steinhardt RA. Evidence for a vesicle-mediated maintenance of store-operated calcium channels in a human embryonic kidney cell line. Cell Calcium 2000; 28: 161-6.

42 Scott TT, Furuta W, Trimble WS, Grinstein S. Activation of store-operated calcium channels: assessment of the role of SNARE-mediated vesicular transport. J Biol Chem 2003; 278: 30534-9.

43 Bakowski D, Burgoyne RD, Parekh AB. Activation of the storeoperated calcium current $I_{\text {CRAC }}$ can be dissociated from plasmalemmal vesicular fusion in RBL-1 cells. J Physiol 2003; 553: 387-93.

44 Roos J, DiGregorio PJ, Yeromin AV, Ohlsen K, Lioudyno M, Zhang S, et al. STIM1, an essential and conserved component of store-operated calcium channel function. J Cell Biol 2005; 169 : 435-45.

45 Liou J, Kim ML, Heo WD, Jones JT, Myers JW, Ferrell JE Jr, Meyer T. STIM is a $\mathrm{Ca}^{2+}$ sensor essential for $\mathrm{Ca}^{2+}$-store-depletion-triggered $\mathrm{Ca}^{2+}$ influx. Curr Biol 2005; 15: 1235-41.

46 Feske S, Gwack Y, Prakriya M, Srikanth S, Puppel SH, Tanasa B, et al. A mutation in Orail causes immune deficiency by abrogating CRAC channel function. Nature 2005; 437: 902-5.

47 Spassova MA, Soboloff J, He LP, Xu W, Dziadek MA, Gill DL. STIM1 has a plasma membrane role in the activation of storeoperated $\mathrm{Ca}(2+)$ channels. Proc Natl Acad Sci USA 2006; 103 : 4040-5.

48 Feske S, Giltnane J, Dolmetsch R, Staudt LM, Rao AK, Disa J, et al. Gene regulation mediated by calcium signals in $\mathrm{T}$ lymphocytes. Nature Immunol 2001; 2: 316-24.

49 Partiseti M, Ledeist F, Hivroz C, Fischer A, Korn H, Choquet D. The calcium current activated by $\mathrm{T}$ cell receptor and store depletion in human lymphocytes is absent in a primary immunodeficiency. J Biol Chem 1994; 269: 32327-35.

50 Parekh AB. Calcium signalling and acute pancreatitis: specific response to a promiscuous messenger. Proc Natl Acad Sci USA 2000; 97: 12933-4.

51 Raraty M, Ward J, Erdemli G, Vaillant C, Neoptolemos JP, Sutton $\mathrm{R}$, et al. Calcium-dependent enzyme activation and vacuole formation in the apical granular region of pancreatic acinar cells.
Proc Natl Acad Sci USA 2000; 97: 13126-31.

52 Quintana A, Griesemer D, Schwarz EC, Hoth M. Calcium-dependent activation of T-lymphocytes. Pflugers Arch 2005; 450: 112 .

53 Dolmetsch RE, Xu K, Lewis RS. Calcium oscillations increase the efficiency and specificity of gene expression. Nature 1998; 392: 933-6.

54 Lewis RS. Calcium oscillations in T-cells: mechanisms and consequences for gene expression. Biochem Soc Trans 2003; 31 (Pt 5): 925-9.

55 Lin S, Fagan KA, Li KX, Shaul WPW, Cooper DMF, Rodman DM. Sustained endothelial nitric oxide-synthase activation requires capacitative $\mathrm{Ca}^{2+}$ entry. J Biol Chem 2000; 275: 1797985 .

56 Chang WC, Parekh AB. Close functional coupling between CRAC channels, arachidonic acid release and leukotriene secretion. J Biol Chem 2004; 279: 29994-9.

57 Wei CY, Huang KC, Chou YH, Hsieh PF, Lin KH, Lin WW. The role of Rho-associated kinase in differential regulation by statins of interleukin-1beta- and lipopolysaccharide-mediated nuclear factor kappaB activation and inducible nitric-oxide synthase gene expression in vascular smooth muscle cells. Mol Pharmacol 2006; 69: 960-7.

58 Chen CC, Chow MP, Huang WC, Lin YC, Chang YJ. Flavonoids inhibit tumor necrosis factor-alpha-induced up-regulation of intercellular adhesion molecule-1 (ICAM-1) in respiratory epithelial cells through activator protein-1 and nuclear factor-kappaB: structure-activity relationships. Mol Pharmacol 2004; 66: 68393.

59 Huang WC, Chen JJ, Inoue H, Chen CC.Tyrosine phosphorylation of I-kappa B kinase alpha/beta by protein kinase C-dependent c-Src activation is involved in TNF-alpha-induced cyclooxygenase-2 expression. J Immunol 2003; 170: 4767-75.

60 Liu YW, Chen CC, Tseng HP, Chang WC. Lipopolysaccharideinduced transcriptional activation of interleukin-10 is mediated by MAPK- and NF-kappaB-induced CCAAT/enhancer-binding protein delta in mouse macrophages. Cell Signal 2006; 18: in press.

61 Liu YW, Tseng HP, Chen LC, Chen BK, Chang WC. Functional cooperation of simian virus 40 promoter factor 1 and CCAAT/ enhancer-binding protein beta and delta in lipopolysaccharideinduced gene activation of IL-10 in mouse macrophages. J Immunol 2003; 171: 821-8.

62 Hung JH, Su IJ, Lei HY, Wang HC, Lin WC, Chang WT, et al. Endoplasmic reticulum stress stimulates the expression of cyclooxygenase-2 through activation of NF-kappaB and pp38 mitogen-activated protein kinase. J Biol Chem 2004; 279: 4638492.

63 Yang CR, Hsieh SL, Ho FM, Lin WW. Decoy receptor 3 increases monocyte adhesion to endothelial cells via NF-kappa Bdependent up-regulation of intercellular adhesion molecule-1, VCAM-1, and IL-8 expression. J Immunol 2005; 174: 1647-56.

64 Crabtree GR, Olson EN. NFAT signaling: choreographing the social lives of cells. Cell 2002; 109(Suppl): S67-79.

65 Flanagan WM, Corthesy B, Bram RJ, Crabtree GR. Nuclear association of a T-cell transcription factor blocked by FK-506 and cyclosporin A. Nature 1991; 352: 803-7.

66 Hogan PG, Chen L, Nardone J, Rao A. Transcriptional regula- 
tion by calcium, calcineurin, and NFAT. Genes Dev 2003; 17 : 2205-32.

67 Ishikawa J, Ohga K, Yoshino T, Takezawa R, Ichikawa A, Kubota $\mathrm{H}$, et al. A pyrazole derivative, YM-58483, potently inhibits store-operated sustained $\mathrm{Ca}^{2+}$ influx and IL-2 production in $\mathrm{T}$ lymphocytes. J Immunol 2003; 170: 4441-9.

68 Cirino G, Fiorucci S, Sessa WC. Endothelial nitric oxide synthase: the Cinderella of inflammation? Trends Pharmacol Sci 2003; 24: $91-5$.

69 Cieslik K, Zembowicz A, Tang JL, Wu KK. Transcriptional regulation of endothelial nitric-oxide synthase by lysophosphatidylcholine. J Biol Chem 1998; 273: 14885-90.

70 Chen PF, Wu KK. Characterization of the roles of the 594-645 region in human endothelial nitric-oxide synthase in regulating calmodulin binding and electron transfer. J Biol Chem 2000; 275: 13155-63.

71 Cieslik K, Abrams CS, Wu KK. Up-regulation of endothelial nitric-oxide synthase promoter by the phosphatidylinositol 3kinase gamma/Janus kinase 2/MEK-1-dependent pathway. J Biol Chem 2001; 276: 1211-9.
72 Wang Y, Shin WS, Kawaguchi H, Inukai M, Kato M, Sakamoto A, et al. Contribution of sustained $\mathrm{Ca}^{2+}$ elevation for nitric oxide production in endothelial cells and subsequent modulation of $\mathrm{Ca}^{2+}$ transient in vascular smooth muscle cells in coculture. Biol Chem 1996; 271: 5647-55.

73 Lin S, Fagan KA, Li KX, Shaul WPW, Cooper DMF, Rodman DM. Sustained endothelial nitric oxide-synthase activation requires capacitative $\mathrm{Ca}^{2+}$ entry. J Biol Chem 2000; 275: 17979 85 .

74 Artalejo AR, Ellory JC, Parekh AB. $\mathrm{Ca}^{2+}$-dependent capacitance increases in rat basophilic leukemia cells following activation of store-operated $\mathrm{Ca}^{2+}$ entry and dialysis with high- $\mathrm{Ca}^{2+}$-containing intracellular solution. Eur J Physiol 1998; 436: 934-9.

75 Samuelsson B, Dahlen SE, Lindgren JA. Leukotrienes and lipoxins: structures, biosynthesis, and biological effects. Science 1987; 237: 1171-6.

76. Chang WC, Nelson C, and Parekh AB. Calcium influx through CRAC channels activates cytosolic phospholipase A2, leukotriene $\mathrm{C} 4$ secretion and expression of c-fos through ERK-dependent and independent pathways. FASEB J 2006: in press. 